\title{
Comparison of African Swine Fever Virus Prevalence in Nigerian Indigenous Pig, Its Hybrid and Backcross in an Environment Prone to African Swine Fever
}

\author{
0. O. Oluwole ${ }^{1,2 *}$, G. O. Omitogun ${ }^{1,2}$, M. O. Oladele-Bukola ${ }^{1,2}$, B. A. Boladuro', \\ ${ }^{1}$ Institute of Agricultural Research and Training, Obafemi Awolowo University, Ibadan, Nigeria \\ ${ }^{2}$ Animal Sciences Department, Faculty of Agriculture, Obafemi Awolowo University, Ile-Ife, Nigeria \\ Email: "oluwafunmike@yahoo.co.uk
}

Received 12 October 2015; accepted 26 January 2016; published 29 January 2016

Copyright (C) 2016 by authors and Scientific Research Publishing Inc.

This work is licensed under the Creative Commons Attribution International License (CC BY).

http://creativecommons.org/licenses/by/4.0/

(c) () Op Den Access

\section{Abstract}

This work investigated on the presence of African swine fever virus (ASFV) in Nigerian Indigenous pig (NIP), its hybrid and backcross using Polymerase chain reaction (PCR) screening method on the extracted DNA and haematological screening from these pig bloods. Pig populations selected from Southwestern Nigeria were used for this study. ASFV infected blood samples collected from the University of Ibadan were used as positive control. White blood cell count was significantly highest in hybrid $\left(31.27 \pm 1.79 \times 10^{3} / \mu \mathrm{l}\right)$ and higher in backcross $\left(27.71 \pm 2.01 \times 10^{3} / \mu \mathrm{l}\right) \mathrm{com}$ pared with NIP $\left(18.16 \pm 3.01 \times 10^{3} / \mu \mathrm{l}\right)$ for NIP, and while Lymphocyte count was found to be highest in hybrid $(86.17 \% \pm 1.95 \%)$ and lowest in backcross $(56.23 \% \pm 1.17 \%)$. The PAS primers (PAS ${ }_{1}$ F: 5'-ATG GAT ACC GAG GGA ATA GC-3' and PAS S $_{2}$ : 5'-CTT ACC GAT GAA AAT GAT AC-3') amplified the 278 bp of ASFV in the DNA extracted from NIP, its hybrids and backcross. In conclusion, this study has shown that NIP, its hybrid and backcross have ASFV in their genome in an ASF-prone environment and thus confirming the continuous prevalence of ASF in Southwest Nigeria. This is an on-going research where the severity and virulence of the virus has to be measured.

\section{Keywords}

Pig, Polymerase Chain Reaction, African Swine Fever

\footnotetext{
${ }^{*}$ Corresponding author.
}

How to cite this paper: Oluwole, O.O., Omitogun, G.O., Oladele-Bukola, M.O. and Boladuro, B.A. (2016) Comparison of African Swine Fever Virus Prevalence in Nigerian Indigenous Pig, Its Hybrid and Backcross in an Environment Prone to African Swine Fever. American Journal of Molecular Biology, 6, 53-62. http://dx.doi.org/10.4236/ajmb.2016.61006 


\section{Introduction}

Pigs play a major role in socioeconomic life of the people; it serves as a source of income for rural population and fulfill important role in culture and food security. The population of pig in Nigeria increases from 2 million in 1984 to 7 million in 1997 before the widespread of ASF epizootic [1].

Disease is one of the factors that affect the livestock production in Nigeria [2]. Jovanoic et al., 2009 [3] stated that diseases can have a significant impact on animal productivity and production, human health and, consequently, on the overall process of economic development Pigs harbor a range of parasites and diseases some of which are zoonotic. One of these is the African Swine Fever that is caused by a virus.

African swine fever (ASF) is a highly contagious viral disease of pigs and of such concern that it is included among the List A diseases by the United Nations Office International des Epizooties (OIE) [4]-[8]. It causes a devastating haemorrhagic fever of pigs with mortality rates approaching $100 \%$ with the acute and peracute forms. It causes major economic losses, threatens food security and limits pig production in affected countries. The disease causes significant economic losses in affected countries due to the high mortality rates associated. The transmission of the disease, as it now occurs in sub-Saharan Africa, is through the African soft tick (Ornithodoros moubata porcinus) and Warthogs or domestic pigs. The transmission through the warthog and soft ticks does not occur in West Africa, although ASF virus has been detected from Warthog in Nigeria of West Africa [9] and also in local pigs in Nigeria [10]. The presence of soft ticks is also confirmed in Warthogs [7].

The diagnosis of infectious diseases such as ASF can be performed by direct and/or indirect detection of infectious agents. By direct methods, the particles of the agents and/or their components, such as nucleic acids, structural or non-structural proteins, enzymes, etc., are detected. The indirect methods demonstrate the antibodies induced by the infections [11]. The most common direct detection methods are isolation or in-vitro cultivation, electron microscopy, immunofluorescence, immunohistochemistry, antigen enzyme-linked immunosorbent assay (antigen-ELISA), nucleic-acid hybridisation (NAH), macro- and microarrays and the various techniques of nucleic acid amplification, such as the polymerase chain reaction (PCR) or the isothermal amplification methods, such as Nucleic Acid Sequence Based Amplification (NASBA), Invader or Loop-Mediated Isothermal Amplification (LAMP). This study aimed at comparing the ASFV prevalence in NIP, its hybrid and backcross in an environment prone to African Swine Fever.

\section{Materials and Method}

\subsection{Blood Sampling}

Blood samples were collected from the jugular vein of pure NIP (20), crossbreds (10) and Backcross [14] into 5 $\mathrm{ml}$ sterile EDTA bottles and brought into the laboratory for haematological analyses and DNA extraction for Polymerase Chain Reaction (PCR).

\subsection{Blood Analysis}

Hematological traits which consist of mainly three components, including leukocyte traits, erythrocyte traits and platelet traits were measured. Blood parameters include leukocyte traits such as White Blood Cell Count (WBC), neutrophil (NEU), lymphocyte count (LY), monocytes (MONO), erythrocyte traits (Red Blood Cell (RBC), Hemoglobin (HGB), Hematocrit or Packed cell volume (PCV), Mean Corpuscular Volume (MCV), Mean Corpuscular Hemoglobin (MCH), Mean Corpuscular Hemoglobin Concentration (MCHC) and platelet trait (blood Platelet counts (PLT). All these blood routine parameters were measured as described by Makinde et al. (1991) [12], Mafuvadze and Erlwanger (2007). The MCV, MCHC and MCH were calculated from PCV, RBC and Hb data as follows; $\mathrm{MCV}=\mathrm{PCV} / \mathrm{RBC}, \mathrm{MCHC}=\mathrm{Hb} / \mathrm{PCV}, \mathrm{MCH}=\mathrm{Hb} / \mathrm{RBC}$.

\subsection{DNA Extraction}

The DNA extraction was done by using DNA kit (Zymobeads). The manufacturer instructions were followed in details.

\subsection{PCR Condition}

Diagnostic Polymerase Chain Reaction was performed according to the Manual of Diagnostic Tests and Vacc- 
ines (OIE, 2008). ASF-specific primers (oligonucleotide primers) targeting the major capsid protein (VP72 gene) amplifying a 278-bp fragment within the conserved region was employed: PAS 1 F: 5'-ATG GAT ACC GAG GGA ATA GC-3' and PAS ${ }_{2}$ R: 5'-CTT ACC GAT GAA AAT GAT AC-3' (Luther et al., 2007; OIE, 2008). The final reaction volume of $25 \mu \mathrm{l}$ PCR master mix comprised $10 \mu$ l extracted DNA template, $10 \mu 1$ Nuclease Free Water, $10 \mu$ loligonucleotide primers (for both Forward and Reverse) and $12 \mu \mathrm{l}$ of already prepared Master Mix. Each tube was placed in an automated PCR thermal cycler (MG48+; Mygene ${ }^{\mathrm{TM}}$ Series) for amplification for 35 cycles as follows: initial denaturation at $94^{\circ} \mathrm{C}$ for 3 minutes for 35 cycles, with 3 steps of denaturation at $94^{\circ} \mathrm{C}$ for 30 seconds, annealing at $57^{\circ} \mathrm{C}$ for 45 seconds and extension at $72^{\circ} \mathrm{C}$ for 30 seconds and final extension at $72^{\circ} \mathrm{C}$ for 5 minutes. Amplification products were analyzed by electrophoresis on a $1 \%$ agarose gel containing $0.5 \mu \mathrm{g}$ of ethidium bromide per ml. The gel were visualized under Ultra violet light and photographed.

\section{Results and Discussion}

\subsection{ASFV Detection}

PAS Primers of ASFV amplify at 278 bp for infected pigs used as positive control, NIP, hybrid and the crossbred. Plate 1 shows single and discrete band of ASFV amplification at 278 bp for NIP and for a positive control sample obtained from the Veterinary Medicine of the University of Ibadan while no band was observed for the negative control.

\subsection{Haematological Status of the NIPs, Hybrid and Backcrosses}

Haematological traits include Leukocyte related traits, red blood cells related traits and platelets traits, which are important components of the animal's immune system. The effect of genotype on the haematological parameters of NIP, Hybrid and Backcross is shown in Table 1. The means of Red Blood Count traits of NIP, hybrid and BC are respectively as follows: PCV $(37.07 \% \pm 1.50 \%, 33.39 \% \pm 1.49 \%, 31.31 \% \pm 0.87 \%)$; $\mathrm{Hb}(12.37 \pm 0.50$ (g/dl), $11.11 \pm 0.50(\mathrm{~g} / \mathrm{dl}), 10.42 \pm 0.29(\mathrm{~g} / \mathrm{dl})) ; \mathrm{RBC}\left(4.41 \pm 2.02\left(\times 10^{6} / \mathrm{ul}\right), 5.31 \pm 3.48\left(\times 10^{6} / \mathrm{ul}\right), 4.65 \pm 3.56\right.$ $\left.\left(\times 10^{6} / \mathrm{ul}\right)\right) ; \operatorname{MCV}(87.45 \pm 0.00 \mathrm{fl}, 68.23 \pm 0.01 \mathrm{fl}, 74.52 \pm 0.01 \mathrm{fl}) ; \mathrm{MCHC}(33.00 \pm 0.00(\mathrm{~g} / \mathrm{dl}), 33.25 \pm 0.00$ (g/dl), $33.27 \pm 0.00(\mathrm{~g} / \mathrm{dl}))$ and MCH $(29.15 \pm 0.00(\mathrm{~g} / \mathrm{dl}), 22.70 \pm 0.00(\mathrm{~g} / \mathrm{dl}), 24.80 \pm 0.00(\mathrm{~g} / \mathrm{dl}))$. The means of Leaukocyte traits of NIP, hybrid and BC are respectively as follows: WBC (18.16 $\pm 3.01\left(\times 10^{3} / \mu \mathrm{l}\right), 31.27 \pm$ $\left.1.79\left(\times 10^{3} / \mu \mathrm{l}\right), 27.71 \pm 2.01\left(\times 10^{3} / \mu \mathrm{l}\right)\right) ; \mathrm{NEU}(18.75 \pm 1.77,12.04 \pm 1.87,40.39 \pm 1.17) ; \mathrm{LYM}(77.89 \pm 1.79$, $86.17 \pm 1.95,56.23 \pm 1.17)$; MONO $(1.64 \% \pm 0.21 \%, 1.04 \% \pm 0.95 \%, 1.54 \% \pm 0.29 \%)$ and EOS $(2.21 \% \pm$ $0.35 \%, 0.70 \% \pm 0.25 \%, 1.92 \% \pm 0.27 \%)$. The means of Platelet trait of NIP, hybrid and BC are respectively as follows: PLT $\left(32.00 \pm 2.08\left(\times 10^{4} / \mathrm{ul}\right), 59.56 \pm 7.44\left(\times 10^{4} / \mathrm{ul}\right), 16.41 \pm 2.20\left(\times 10^{4} / \mathrm{ul}\right)\right)$. It was observed that effect of breed was significant $(\mathrm{P}<0.05)$ in all the Leukocyte-related traits with the exception of the Monocyte. Hybrid had higher values than NIP and Backcross in WBC and LYM with $31.27 \%$ and $86.17 \%$ values respectively. The backcrosses had higher value of $40.39 \% \pm 1.17 \%$ in Neutrophil compared to hybrid and NIP while the NIP had higher values of Monocytes and Eosinophil $(1.64 \% \pm 0.21 \%$ and $2.21 \% \pm 0.35 \%)$ compared to hybrid

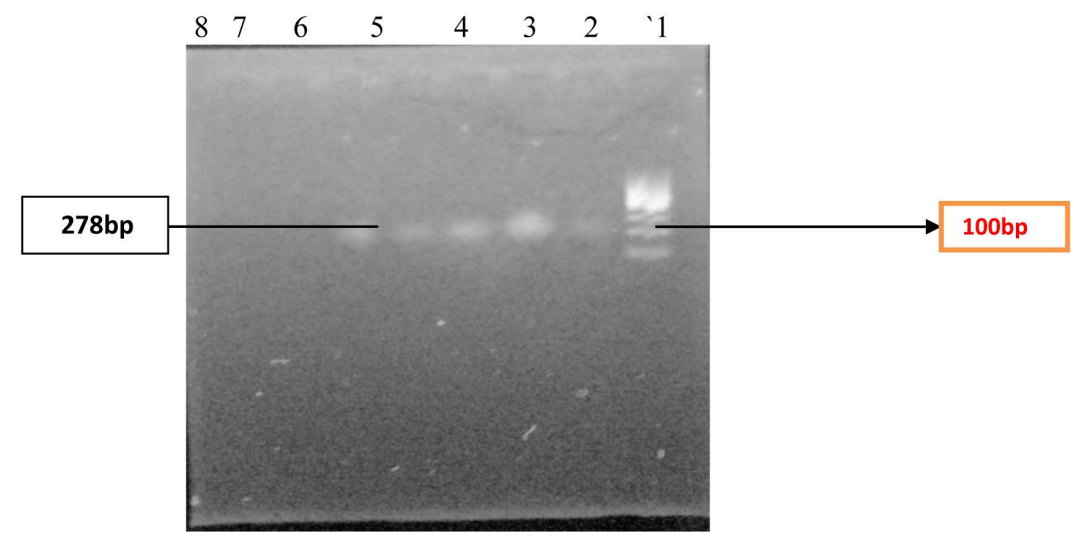

Plate 1. ASFV amplification in NIP DNA using PAS primer (278 bp) in lanes 2 - 5; lane 6 is the positive control; lane 7 is negative control. Molecular marker (100 bp) in Lane 1. 
Table 1. Effect of genotype on the haematological parameters of NIP, Hybrid and Backcross.

\begin{tabular}{|c|c|c|c|c|}
\hline & \multirow[t]{2}{*}{ Variables } & \multicolumn{3}{|c|}{ Mean } \\
\hline & & NIP & Hybrid & Backcross \\
\hline $\mathrm{n}$ & & 28 & 23 & 13 \\
\hline \multirow{6}{*}{ Red blood cell count } & ${ }^{*} \mathrm{PCV}(\%)$ & $37.07 \pm 1.50 \mathrm{a}$ & $33.39 \pm 1.49 \mathrm{ab}$ & $31.31 \pm 0.87 b$ \\
\hline & ${ }^{*} \mathrm{Hb}((\mathrm{g} / \mathrm{dl}))$ & $12.37 \pm 0.50 \mathrm{a}$ & $11.11 \pm 0.50 \mathrm{ab}$ & $10.42 \pm 0.29 b$ \\
\hline & $\operatorname{RBC}\left(10^{6} / \mathrm{ul}\right)$ & $4.41 \pm 2.02$ & $5.31 \pm 3.48$ & $4.65 \pm 3.56$ \\
\hline & ${ }^{*} \mathrm{MCV}((\mathrm{fl}))$ & $87.45 \pm 0.00 \mathrm{a}$ & $68.23 \pm 0.01 \mathrm{ab}$ & $74.52 \pm 0.01 b$ \\
\hline & MCHC (g/dl) & $33.00 \pm 0.00$ & $33.25 \pm 0.00$ & $33.27 \pm 0.00$ \\
\hline & ${ }^{*} \mathrm{MCH}$ (pg) & $29.15 \pm 0.00 \mathrm{a}$ & $22.70 \pm 0.00 \mathrm{~b}$ & $24.80 \pm 0.00 \mathrm{ab}$ \\
\hline \multirow{5}{*}{ White blood count } & ${ }^{*} \mathrm{WBC}\left(\times 10^{3} / \mu \mathrm{l}\right)$ & $18.16 \pm 3.01 b$ & $31.27 \pm 1.79 a$ & $27.71 \pm 2.01 \mathrm{c}$ \\
\hline & ${ }^{*} \mathrm{NEU}(\%)$ & $18.75 \pm 1.77 b$ & $12.04 \pm 1.87 \mathrm{c}$ & $40.39 \pm 1.17 a$ \\
\hline & ${ }^{*} \mathrm{LYM}(\%)$ & $77.89 \pm 1.79 b$ & $86.17 \pm 1.95 a$ & $56.23 \pm 1.17 \mathrm{c}$ \\
\hline & MON (\%) & $1.64 \pm 0.21$ & $1.04 \pm 0.95$ & $1.54 \pm 0.29$ \\
\hline & ${ }^{*}$ EOSI & (\%) & $2.21 \pm 0.35 a$ & $0.70 \pm 0.25 b$ \\
\hline Platelet & ${ }^{*}$ PLT $\left(\times 10^{4} / \mathrm{ul}\right)$ & $32.00 \pm 2.08 b$ & $59.56 \pm 7.44 a$ & $16.41 \pm 2.20 \mathrm{c}$ \\
\hline
\end{tabular}

${ }^{\mathrm{a}, \mathrm{b}, \mathrm{c}}$ Mean within the same row with different superscript letters, were different $(\mathrm{P}<0.05)^{*}$ Level of Significance $(\mathrm{P}<0.05)$. PCV—Packed cell volume, RBC—Red blood cell count, Hb-Hemoglobin, WBC-White blood cell, NEU-Neutrophil, LYMLymphocyte, EOS—Eosinophil, MON_Monocytes, MCV—Mean Corpuscular Volume, MCH—Mean Corpuscular Haemoglobin, MCHC_Mean Corpuscular Haemoglobin Concentration, PLT-Platelet.

and backcross respectively. The backcross and Hybrid had WBC values of $27.71 \pm 2.01 \times 10^{3} / \mu \mathrm{l}$ and $31.27 \pm$ $1.79 \times 10^{3} / \mu$ l respectively which were higher than the normal range ( 7 to $\left.20 \times 10^{3} / \mu l\right)$ while the NIP value $\left(18.16 \pm 3.01 \times 10^{3} / \mu \mathrm{l}\right)$ was within the normal range. The NIP and Hybrid had low Neutrophil values of $18.75 \%$ $\pm 1.77 \%$ and $12.04 \% \pm 1.87 \%$ respectively. It was observed (Table 1 ) that all the red blood parameters were significant $(\mathrm{P}<0.05)$ with the exception of RBC and MCHC. NIP had higher values than the Hybrid and Backcross with the exception of RBC where the Hybrid had the highest value of 5.31(10 $/ \mathrm{ul})$. The effect of genotype on Platelet value was significant $(\mathrm{P}<0.05)$.

The effect of sex on the haematological parameters of NIP, Hybrid and Backcross is presented in Table 2. The means of Red Blood Count traits of male and female are as follow respectively: PCV $(32.09 \% \pm 0.83 \%$, $37.23 \% \pm 1.51 \%) ; \mathrm{Hb}(10.70 \pm 0.28(\mathrm{~g} / \mathrm{dl}), 12.38 \pm 0.51(\mathrm{~g} / \mathrm{dl})) ; \mathrm{RBC}\left(4.72 \pm 2.76\left(\times 10^{6} / \mathrm{ul}\right), 4.85 \pm 2.12\right.$ $\left.\left(\times 10^{6} / \mathrm{ul}\right)\right) ; \mathrm{MCV}(75.63 \pm 0.01 \mathrm{fl}, 80.35 \pm 0.00 \mathrm{fl}) ; \mathrm{MCHC}(33.33 \pm 0.00(\mathrm{~g} / \mathrm{dl}), 33.26 \pm 0.00(\mathrm{~g} / \mathrm{dl}))$ and MCH (25.21 $\pm 0.00 \mathrm{pg}, 26.73 \pm 0.00 \mathrm{pg})$. The means of Leaukocyte traits of NIP, hybrid and BC are respectively as follows: WBC $\left(24.16 \pm 7.68\left(\times 10^{3} / \mu \mathrm{l}\right), 25.50 \pm 7.28\left(\times 10^{3} / \mu \mathrm{l}\right)\right)$; NEU $(21.51 \% \pm 2.21 \%, 19.90 \% \pm 2.55 \%)$; LYM $(75.15 \% \pm 2.26 \%, 77.87 \% \pm 2.66 \%)$; MONO $(1.27 \% \pm 0.15 \%, 1.55 \% \pm 0.22 \%)$ and EOS $(2.12 \% \pm 0.30 \%$, $1.07 \% \pm 0.24 \%$ ). The means of Platelet trait of NIP, hybrid and BC are respectively as follow: PLT (33.96 \pm $\left.3.53\left(\times 10^{4} / \mathrm{ul}\right), 43.82 \pm 6.14\left(\times 10^{4} / \mathrm{ul}\right)\right)$. The effect of sex was non-significant $(\mathrm{P}>0.05)$ in all the white blood parameters with the exception of Eosinophil $(2.12 \% \pm 0.30 \%)$. Among the red blood parameters, the effect of sex was observed to be significant ( $<$ 0.05) in only PCV, Hb and MCV while the RBC, MCHC and MCH were not significant $(\mathrm{P}>0.05)$. The values obtained for MCV and MCH, ranging from 68.23 - $87.45 \mathrm{fl}$, were greater than the normal range (50 - $68 \mathrm{fl}$ ) for pigs. It was only the Hybrid that it's MCV $(68.23 \mathrm{fl})$ is within the normal range while NIP $(87.45 \mathrm{fl})$ and Backcross $(74.52 \mathrm{fl})$ values were greater. The Platelet value was significant $(\mathrm{P}<$ $0.05)$ with sex.

The Pearson correlation tables for haematological traits of Hybrid, NIP and backcross respectively are presented in Tables 3-5. There was high positive correlation (1.00) between Packed Cell Volume and haemoglobin in all the three breeds; and there was negative correlation $(-0.99,-0.97$ and -0.96$)$ between Neutrophil and the Lymphocyte of Hybrid, Backcross and NIP respectively. This negative correlation between the Neutrophil and Lymphocyte mean that increase in Neutrophil will cause decrease in Lymphocyte. 
Table 2. Effect of sex on the haematological traits of NIP, hybrid and backcross.

\begin{tabular}{|c|c|c|c|}
\hline & \multirow[t]{2}{*}{ Variables } & \multicolumn{2}{|c|}{ Mean } \\
\hline & & Male (33) & Female (31) \\
\hline \multirow{6}{*}{ Red blood cell count } & "PCV (\%) & $32.09 \pm 0.83 b$ & $37.23 \pm 1.51 \mathrm{a}$ \\
\hline & ${ }^{*} \mathrm{Hb}$ & $(\mathrm{g} / \mathrm{dl})$ & $10.70 \pm 0.28 \mathrm{~b}$ \\
\hline & $\mathrm{RBC}\left(\times 10^{6} / \mathrm{ul}\right)$ & $4.72 \pm 2.76$ & $4.85 \pm 2.12$ \\
\hline & ${ }^{*} \mathrm{MCV}(\mathrm{fl})$ & $75.63 \pm 0.01 b$ & $80.35 \pm 0.00 \mathrm{a}$ \\
\hline & MCHC (g/dl) & $33.33 \pm 0.00$ & $33.26 \pm 0.00$ \\
\hline & MCH (pg) & $25.21 \pm 0.00$ & $26.73 \pm 0.00$ \\
\hline \multirow{5}{*}{ White blood count } & WBC $\left(\times 10^{3} / \mu \mathrm{l}\right)$ & $24.16 \pm 7.68$ & $25.50 \pm 7.28$ \\
\hline & NEU (\%) & $21.51 \pm 2.21$ & $19.90 \pm 2.55$ \\
\hline & LYM (\%) & $75.15 \pm 2.26$ & $77.87 \pm 2.66$ \\
\hline & MON (\%) & $1.27 \pm 0.15$ & $1.55 \pm 0.22$ \\
\hline & ${ }^{*}$ EOS (\%) & $2.12 \pm 0.30 \mathrm{a}$ & $1.07 \pm 0.24 \mathrm{~b}$ \\
\hline Platelets & ${ }^{*} \mathrm{PLT}\left(\times 10^{4} / \mathrm{ul}\right)$ & $33.96 \pm 3.53 b$ & 43.82 \\
\hline
\end{tabular}

${ }_{\mathrm{a}, \mathrm{b}}$ Mean within the same row with different superscript letters, were different $(\mathrm{P}<0.05)^{*}$ Level of significance $(\mathrm{P}<0.05)$. PCVPacked cell volume, RBC—Red blood cell count, Hb-Hemoglobin, Leu-Leucocyte, NEU-Neutrophil, LYM-Lymphocyte, EOS—Eosinophil, MON_-Monocytes, MCV—Mean Corpuscular Volume, MCH—Mean Corpuscular Haemoglobin, MCHC- Mean Corpuscular Haemoglobin Concentration, PLT-Platelet.

Table 3. Pearson correlation coefficients for haematological traits of NIP.

\begin{tabular}{|c|c|c|c|c|c|c|c|c|c|c|c|c|}
\hline & PCV & HB & $\mathrm{RBC}$ & MCV & $\mathrm{MCHC}$ & $\mathrm{MCH}$ & WBC & NEU & LYM & MONO & EOSI & PLT \\
\hline PCV & 1.00 & 1.00 & *0.55 & 0.25 & -0.01 & 0.25 & -0.23 & -0.10 & 0.13 & 0.12 & -0.30 & 0.08 \\
\hline HB & & 1.00 & ${ }^{*} 0.55$ & 0.24 & 0.06 & 0.24 & -0.23 & -0.11 & 0.15 & 0.13 & -0.29 & 0.08 \\
\hline $\mathrm{RBC}$ & & & 1.00 & ${ }^{*}-0.64$ & 0.07 & ${ }^{*}-0.64$ & ${ }^{*}-0.43$ & -0.34 & 0.30 & 0.04 & 0.20 & 0.08 \\
\hline MCV & & & & 1.00 & -0.08 & 1.00 & 0.34 & 0.26 & -0.20 & 0.14 & - & 0.38 \\
\hline MCHC & & & & & 1.00 & -0.03 & -0.03 & -0.20 & 0.19 & 0.12 & -0.03 & 0.07 \\
\hline $\mathrm{MCH}$ & & & & & & 1.00 & 0.34 & 0.25 & -0.19 & 0.15 & -0.38 & 0.02 \\
\hline WBC & & & & & & & 1.00 & "0.61 & ${ }^{*} 0.56$ & -0.18 & 0.17 & -0.36 \\
\hline NEU & & & & & & & & 1.00 & -0.96 & -0.23 & -0.13 & ${ }^{*} 0.46$ \\
\hline LYM & & & & & & & & & 1.00 & 0.15 & 0.09 & ${ }^{*} 0.50$ \\
\hline MON & & & & & & & & & & 1.00 & 0.25 & 0.16 \\
\hline EOSI & & & & & & & & & & & 1.00 & 0.03 \\
\hline PLT & & & & & & & & & & & & 1.00 \\
\hline
\end{tabular}

Level of significance $\mathrm{P}<0.05$. PCV—Packed cell volume, RBC—Red blood cell count, Hb—Hemoglobin, WBC—White blood cell, NEU—Neutrophil, LYM-Lymphocyte, EOS—Eosinophil, MON—Monocytes, MCV-Mean Corpuscular Volume, MCH—Mean Corpuscular Haemoglobin, MCHC—Mean Corpuscular Haemoglobin Concentration, PLT—Platelet.

\subsection{ASFV Amplification for NIP, Hybrid and Backcross}

The 278 bp of ASFV observed in NIP can be corroborated with the findings of Luther et al. (2007) [9] and Luther et al. (2008) [13], where the same virus band was observed in Bushpigs and Warthogs tested at National Veterinary Research Institute (NVRI), Jos. The presence of ASFV in NIP for long period without any clinical symptom or death was explained by Adeoye and Adebambo (2010) [14] and Oluwole and Omitogun (2013) [10] by the ability of the pigs to trap ASFV within their tissues by the activities of macrophages that eat up the pathogens and infected tissues so that other parts and their mast cells in the tissues are not affected. 
Table 4. Pearson correlation coefficient for haematological traits of hybrid.

\begin{tabular}{|c|c|c|c|c|c|c|c|c|c|c|c|c|}
\hline & PCV & HB & $\mathrm{RBC}$ & MCV & MCHC & $\mathrm{MCH}$ & WBC & NEU & LYM & MONO & EOSI & PLT \\
\hline PCV & 1.00 & 1.00 & 0.04 & ${ }^{*} 0.57$ & 0.16 & ${ }^{*} 0.56$ & 0.19 & -0.13 & 0.08 & 0.18 & 0.21 & 0.15 \\
\hline $\mathrm{HB}$ & & 1.00 & 0.03 & ${ }^{*} 0.56$ & 0.19 & ${ }^{*} 0.56$ & 0.19 & -0.12 & 0.08 & 0.18 & 0.21 & 0.14 \\
\hline RBC & & & 1.00 & -0.73 & -0.20 & -0.73 & -0.03 & -0.20 & 0.21 & 0.20 & 0.30 & 0.19 \\
\hline $\mathrm{MCV}$ & & & & 1.00 & 0.21 & 1.00 & 0.10 & 0.18 & -0.22 & 0.04 & 0.37 & 0.08 \\
\hline MCHC & & & & & 1.00 & 0.22 & 0.10 & 0.12 & -0.12 & 0.10 & -0.03 & -0.36 \\
\hline $\mathrm{MCH}$ & & & & & & 1.00 & 0.11 & 0.18 & -0.22 & 0.04 & 0.37 & 0.07 \\
\hline WBC & & & & & & & 1.00 & -0.25 & 0.25 & 0.22 & -0.22 & 0.01 \\
\hline NEU & & & & & & & & 1.00 & -0.99 & -0.15 & 0.40 & -0.01 \\
\hline LYM & & & & & & & & & 1.00 & 0.05 & ${ }^{*}-0.50$ & 0.01 \\
\hline MON & & & & & & & & & & 1.00 & 0.01 & 0.33 \\
\hline EOSI & & & & & & & & & & & 1.00 & -0.27 \\
\hline PLT & & & & & & & & & & & & 1.00 \\
\hline
\end{tabular}

${ }^{*}$ Level of significance $\mathrm{P}<0.05$. PCV—Packed cell volume, RBC—Red blood cell count, Hb-Hemoglobin, Leu—Leucocyte, NEU— Neutrophil, LYM - Lymphocyte, EOS—Eosinophil, MON-Monocytes, MCV—Mean Corpuscular Volume, MCH—Mean Corpuscular Haemoglobin, MCHC-Mean Corpuscular Haemoglobin Concentration, PLT—Platelet.

Table 5. Pearson correlation coefficients for haematological traits of backcross.

\begin{tabular}{|c|c|c|c|c|c|c|c|c|c|c|c|c|}
\hline & PCV & HB & $\mathrm{RBC}$ & MCV & MCHC & $\mathrm{MCH}$ & WBC & NEU & LYM & MONO & EOSI & PLT \\
\hline PCV & 1.00 & 1.00 & 0.45 & -0.01 & -0.23 & -0.01 & -0.07 & -0.06 & -0.08 & ${ }^{*} 0.61$ & 0.26 & 0.20 \\
\hline $\mathrm{HB}$ & & 1.00 & 0.45 & -0.00 & -0.02 & ${ }^{*} 0.00$ & -0.07 & -0.05 & -0.10 & ${ }^{*} 0.62$ & 0.27 & 0.20 \\
\hline RBC & & & 1.00 & ${ }^{*}-0.84$ & -0.14 & ${ }^{*}-0.84$ & 0.11 & 0.14 & -0.17 & 0.06 & 0.35 & -0.09 \\
\hline MCV & & & & 1.00 & 0.12 & 1.00 & -0.16 & 0.12 & 0.06 & 0.29 & -0.12 & 0.19 \\
\hline MCHC & & & & & 1.00 & 0.12 & -0.04 & 0.27 & -0.29 & 0.10 & 0.24 & 0.09 \\
\hline $\mathrm{MCH}$ & & & & & & 1.00 & -0.16 & -0.12 & 0.05 & 0.29 & -0.12 & 0.19 \\
\hline WBC & & & & & & & 1.00 & -0.17 & 0.25 & -0.24 & -0.16 & 0.10 \\
\hline NEU & & & & & & & & 1.00 & -0.97 & -0.09 & ${ }^{*} 0.65$ & -0.07 \\
\hline LYM & & & & & & & & & 1.00 & -0.07 & ${ }^{*}-0.66$ & 0.03 \\
\hline MON & & & & & & & & & & 1.00 & 0.21 & 0.43 \\
\hline EOSI & & & & & & & & & & & 1.00 & -0.01 \\
\hline PLT & & & & & & & & & & & & 1.00 \\
\hline
\end{tabular}

Level of significance P $<0.05$. PCV—Packed cell volume, RBC—Red blood cell count, Hb-Hemoglobin, WBC—White blood cell, NEU-Neutrophil, LYM-Lymphocyte, EOS-Eosinophil, MON-Monocytes, MCV-Mean Corpuscular Volume, MCH-Mean Corpuscular Haemoglobin, MCHC_-Mean Corpuscular Haemoglobin Concentration, PLT—Platelet.

The Hybrid and backcross also showed the presence of ASFV. This result was corroborated with the findings of Adeoye and Adebambo (2010) [14], where serological tests showed the presence of ASFV in crossbreds. The hybrid and the backcross showing the presence of ASFV was not surprising as ASFV were present in the NIP parent. This observation in hybrid and backcross was reported in their work where serological tests were carried out on ASF outbreak survivors, their offspring and $\mathrm{F}_{2}$ showed a decline in antibody levels against ASF from $100 \%$ to $18.79 \%$. This phenomenon was explained as the ability of engulfed ASFV to be broken down easily and effectively by macrophages leading to decreasing circulation of ASFV in the blood and other tissues. Thus, the amount of shed ASFV particles observed in urine and feaces was seen to drop significantly in the offspring. This observation was also corroborated by Olugasa et al. (2007) [15] who also reported that the level of infection in the serum dropped from parents with $96.8 \%$ to $13.8 \%$ in their offspring. 
The ability of the virus to persist in one host while killing another genetically related host was established by Palgrave et al. (2011) [16] where a particular sequence found in warthog and bush pigs was absent in domestic pigs.

\subsection{Leukocyte Traits in NIP, Hybrid and Backcross}

The White Blood Cell (WBC) count is a powerful indicator for infectious and inflammatory disease, leukemia, lymphoma and bone marrow disorders. WBC was found to be higher in backcross compared with NIP and highest in hybrid (Table 1). WBC was high in Hybrid because it increased to fight against the virus. Thus, the Leukocyte traits obtained from this study were indications of NIP and backcross been exposed to ASFV and the susceptibility of hybrid to the virus. WBC of NIP $\left(18.16 \pm 3.01 \times 10^{3} / \mu \mathrm{l}\right)$ was within the normal range $(7$ to $20 \times$ $\left.10^{3} / \mu \mathrm{l}\right)$ for domestic pigs while WBC of hybrid and backcross values of $31.27 \pm 1.79 \times 10^{3} / \mu \mathrm{l}$ and $27.71 \pm 2.01$ $\times 10^{3} / \mu \mathrm{l}$ were higher than the normal range (7 to $20 \times 10^{3} / \mu \mathrm{l}$ ) (Table A1 in Appendix). This deviation from normal range for domestic pig was also observed to be in agreement with Karalyan (2012) [17], Anderson (1998) [18] and Eze et al. (2010) [19] where the WBC $\left(25.92 \pm 8.08 \times 10^{3} / \mu \mathrm{l}\right)$ of the pigs from South-East of Nigeria were higher than the normal or physiological values ( 7 to $20 \times 10^{3} / \mu \mathrm{l}$ ). The observed increase in WBC of Hybrid and backcross was adduced to a probable virus inducement of mass-scale mortality of lymphocytes and neutrophils causing the presence of additional nucleus as reported by Karalyan (2012) [17] and Anderson (1998) [18]. Karalyan (2012) [19] also reported that ASFV infection leads to serious changes in composition of WBC. Stress effects induced due to the presence of pathogen was also presented as a possible cause of increase in WBC [17] [18]. The same trend as observed in WBC was observed in neutrophil and Eosinophil of male and female pigs (Table 2). Scientists reported that the neutrophil percentage increased during stress [20]. The significance of increase in Eosinophil of females (1.07\%) compared to 2.12\% in males in Table 2 might be due to stress that may be caused by the ASF diseases. Addah et al. (2007) [21] reported that high Eosinophil is responsible for the stress, and diseases [22].

\subsection{Red Blood Cell Count in NIP, Hybrid and Backcross}

Red blood cell parameters are important innate immune cells in blood circulation and they can recognize antigen, kill antigen, they are also involved in immune regulation and have a complete self-regulation system. The RBC of hybrid, NIP and BC were not significant varied from each other from the study. This finding was contrary to findings of De et al. (2013) [23] where the PCV values of local pigs of India were significantly different from that of the exotic pigs. In this study, values for RBC, PCV and Hb were observed to be within normal range. Karalyan et al. (2012) [17] suggested that ASFV directly or indirectly influenced the haematopoietic homeostasis through activation or impaired haematopoiesis [17] [24]. Also Wardley and Wilkinson (1977) [25] and Quintero et al. (1986) [26] reported that ASFV is associated with RBC. Karalyan et al. (2014) [19] reported that from the beginning of infection, juvenile forms of RBC, such as the largest cells were observed in the peripheral blood of infected pigs. Among the erythroid precursors, up to $60 \%$ of all cells were binucleated, which indicates that acute ASFV infection is accompanied by the emergence of pathological forms of RBC.

The insignificant effect of sex on MHCH and MCH is also corroborated [27] [28].

\subsection{Platelet Count in NIP, Hybrid and Backcross}

The significant effect of breed on platelet trait was in line with findings of De et al. (2013) [23] where the variation between the local breed from India and exotic pigs were significant. Platelet trait in this study for NIP and Hybrid were within the normal range (but that of Hybrid was higher than that of NIP) while the backcross value was lower than the normal range for the domestic pigs. Platelet trait is one of the inflammation signals. Gomez-Vilamandos et al. (1996) [24] reported that platelets assist in dissemination of ASFV within infected pig body particularly in sub-acute infection while Anderson (1998) [18] reported that platelet count decreases during acute infections of ASF.

\section{Conclusions}

In conclusion, ASFV was present in NIP, hybrid and the backcross. The inflammation signal (white blood count, red blood count and platelet count) in hybrid was higher than that of NIP and backcross. ASF in West African 
countries especially Nigeria, has become endemic because of the continuous occurring of the intermittent infections. This disease causes large fatalities in pigs and consequently significant loss of income and employment opportunities [29]. It has an overall effect on the pig industry worldwide, because it limits opportunities to explore external markets and increase rapidity/possibilities of inter-continental contamination.

When the presence of the virus is identified, the focus should be on environmental risks and biosecurity in pig. Fashina [30] reported that 306 pig farms and 91\% of the 31,916 affected pigs succumbed to the disease in Ibadan (2001), South west Nigeria. Compulsory slaughtering of infected animals and animals at risk, without any compensation to the owners, has dramatic effect on the piggery farmers. The threat of losing their animals with no recompense, drives pig-keepers to do two things to cut their losses, If possible, they will move their animals away from the infected areas, maybe to relatives in neighboring states or countries. In this part of Africa, where sociocultural ties exist regardless of national boundaries, it is relatively easy to move animals over the border to kinsfolk, thereby causing the spread of the disease.

\section{References}

[1] Dafwang, I.I., Adebambo, O.A. and Adesehinwa, A.O.K. (2010) Status of Pigs Production and Marketing in Nigeria: An Overview of Current Practises, Problems and Prospects. First Nigerian International Pig Summit, 22-25 November 2010, Institute of Agricultural Research Institute, Ibadan, 1-17.

[2] Abubakar, M.B., Ngele, D.J.N. and Achaji, M.B. (2003) Problems of Annual Livestock Production in Nigeria. A Case Study of Akko Local Government Area of Gombe State. Proceedings of the 28th Conference of the Nigerian Society for Animal Production, 71-73.

[3] Jovanović, S.M., Savić1, D. and Živković, M. (2009) Genetic Variation in Disease Resistance among Farm Animals. Biotechnology in Animal Husbandry, 25, 339-347. http://dx.doi.org/10.2298/BAH0906339J

[4] Owolodun, O.A., Bastos, A.S., Antiabong, J.F., Ogedengbe, M.E., Ekong, P.S. and Yakubu, B. (2010) Molecular Characterisation of African Swine Fever Viruses from Nigeria (2003-2006) Recovers Multiple Virus Variants and Reaffirms CVR Epidemiological Utility. Springer Science Media.

[5] Sanchez-Vizcaino, J.M., Martinez-Lopez, B., Martinez-Aviles, M., Martins, C., Boinas, F., Vial, L., Michaud, V., Jori, F., Etter, E., Albina, E. and Roger, F. (2009) Scientific Review on African Swine Fever. Scientific Report Submitted to EFSA, 1-141.

[6] OIE (World Organisation for Animal Health) (2008) Manual of Diagnostic Tests and Vaccines for Terrestrial Animals. 5th Edition, OIE, Paris, 957. http://www.oie.int/eng/en_index.htm

[7] Penrith, M.L., Thomson, G.R., Bastos, A.D.S., Phiri, O.C., Lubisi, B.A., Du Plessis, E.C., Macome, F., Pinto, F., Botha, B. and Esterhuysen, J. (2004) An Investigation into Natural Resistance to African Swine Fever in Domestic Pigs from an Endemic Area in Southern Africa. Review Science Technology of International Office Epizoonotic, 23, 965-977.

[8] Food and Agriculture Organization of the United Nations (FAO) (2010) The State Capacities of Animal Genetic Resources Management Rome.

[9] Luther, N.J., Udeama, P.G., Majiyagbe, K.A., Shamaki, D., Antiabong, J., Bitrus, Y., Nwosuh, C.I. and Owolodun, O.A. (2007) Polymerase Chain Reaction (PCR) Detection of the Genome of African Swine Fever Virus (ASFV) from Natural Infection in a Nigerian Baby Warthog (Phacochoereus aethiopicus). Nigerian Veterinary Journal, 28, 63-67.

[10] Oluwole, O.O. and Omitogun, G.O. (2013) Polymerase Chain Reaction Detection of ASFV Genome in Nigerian Indigenous Pigs. America Journal of Microbiology, 4.

[11] OIE (2009) Office International des Epizooties—World Animal Health Informatio Database (WAHID) Interface. http://www.oie.int/wahis/public.php?page=home

[12] Makinde, M.O., Otesile, E.B. and Fagbemi, B.O. (1991) Studies on the Relation between Energy Levels and the Severity of Trypanosoma brucei Infection: The Effect of Diet and Infection on Blood Plasma Volumes and Erythrocytes Osmotic Fragility on Growing Pigs. Bulletin of Animal Health and Production in Africa, 31, 161-166.

[13] Luther, N.J., Majiyagbe, K.A., Shamaki, D., Lombin, L.H., Antiagbong, J.F., Bitrus, Y. and Owolodun, O. (2007) Detection of African Swine Fever Virus Genomic DNA Nigerian Red River Hog (Potamochoerus porcus). Veterinary Research, 160, 58-59.

[14] Adeoye, A.O. and Adebambo, A.O. (2010) Evaluation of Litter Traits of Pigs in an African Swine Fever (ASF) Prone Environment. In: Proceedings of the First Nigerian International Pig Summit, Nigerian Institute Animal science, Institute of Agricultural Research and Training, Moor Plantation, Ibadan, 114-124.

[15] Olugasa, B. (2007) Serological Evidence of African Swine Fever Virus Infection in Commercial Pig Heard in South West Nigeria. African Journal of Livestock Extension, 5, 61-64.

[16] Palgrave, C.J., Gilmour, L., Lowden, S., Simon, G., Martha, L., Mellencamp, A. and Whitelaw, C.A. (2011) Pathoge- 
nesis Potential Role in African Swine Fever Underlies Differences in NF- $\kappa$ B Activity: A Species-Specific Variation in RELA. Journal of Virology, 85, 6008-6014. http://dx.doi.org/10.1128/JVI.00331-11

[17] Karalyan, Z., Zakaryan, H., Arzumanyan, H., Sargsyan, K., Voskanyan, H., Hakobyan, L., Abroyan, L., Avetisyan, A. and Karalova, E. (2012) Pathology of Porcine Peripheral/White Blood Cells during Infection with African Swine Fever Virus. Veterinary Research, 8, 18. http://dx.doi.org/10.1186/1746-6148-8-18

[18] Anderson, E.C., Hutchings, G.H., Mukarati, N. and Wilkinson, P.J. (1998) African Swine Fever Virus Infection of the Bushpig (Potamochoerus porcus) and Its Significance in the Epidemiology of the Disease. Veterinany Microbiology, 62, 1-15. http://dx.doi.org/10.1016/S0378-1135(98)00187-4

[19] Karalyan, Z., Karalov, E., Voskanyan, H., Nersisyan, N., Abroyan, L., Arzumanyan, H., Zakaryan, H. and Karalyan, L. (2014) Evaluating Porcine Red Blood Cells in Acute African Swine Fever Virus (Genotype II) Infection in Peripheral Blood. Journal of Advances in Biology, 3, 227-232.

[20] Mc Clone, J. and Pond, W. (2012) Pig Production: Biological Principles and Applications. Thomson-Delmar Learning, Florence.

[21] Addah, W., Opong, M.A. and Oppong-Anane, K. (2007) Effects of Pre-Slaughter Transportation Stress on Some Haematological Parameters of Small Ruminants. Ghanaian Journal of Animal Science, 3, 193-199.

[22] Addah, W. and Yakubu, P. (2008) Comparative Study of the Effects of Gastrointestinal Parasites on Differential Leukocyte Profile of Djallonke Sheep Kept under Extensive and Semi Intensive Managements Systems in the Northern Ghana. Nigerian Veterinary Journal, 29, 1-10.

[23] De, A.K., Kundu, A., Kundu, M.S., Sunder, J. and Jeyakumar, S. (2013) Comparative Study on Haematological Traits of Endangered Andaman Wild Pig and Other Indigenous Pig Breeds Available at Andaman and Nicobar Islands, India. Veterinary World, 6, 794-798. http://dx.doi.org/10.14202/vetworld.2013.794-798

[24] Gómez-Villamandos, J.C., Bautista, M.J., Hervás, J., Carrasco, L., de Lara, F.C.M., Pérez, J., Wilkinson, P.J. and Sierra, M.A. (1996) Subcellular Changes in Platelets in Acute and Subacute African Swine Fever. Journal of Comparative Pathology, 115, 327-341. http://dx.doi.org/10.1016/S0021-9975(96)80069-7

[25] Wardley, R.C. and Wilkinson, P.J. (1977) The Association of African Swine Fever Virus with Blood Components of Infected Pigs. Archiology Virology, 55, 327-334. http://dx.doi.org/10.1007/BF01315054

[26] Quintero, J.C., Wesley, R.D., Whyard, T.C., Gregg, D. and Mebus, C.A. (1986) In Vitro and in Vivo Association of African Swine Fever Virus with Swine Erythrocytes. America Journal Veterinary Research, 47, 1125-1131.

[27] Miller, E.R., Ullrey, D.E., Ackermann, I., Schmidt, D.A., Luecke, R.W. and Hoefer, J.A. (1961) Population, Size and Haemoglobin Concentration Swine Haematology from Birth to Maturity. II. Erythrocyte. Journal of Animal Science, 20, 890-897.

[28] Eze, J.I., Onunkwo, J.I., Shoyinka, S.V.O., Chah, F.K., Ngene, A.A., Okolinta, N., Nwanta, J.A. and Onyenwe, I.W. (2010) Haematological Profiles of Pigs Raised under Intensive Management System in South-Eastern Nigeria. Nigerian Veterinary Journal, 31, 115-123.

[29] Food and Agriculture Organization of the United Nations (2012) Animal Genetic Resources and Resistance to Disease. FAO, Rome, 108-110.

[30] Fashina, F.O., Lazarus, D.D., Shamaki, D., Makinde, A.A. and Lombin, L.H. (2010) Field Surveillance and Laboratory Diagnosis of African Swine Fever in Nigeria. Proceedings of the First Nigerian International Pig Summit, Ibadan, 22-25 November 2010, 168-170. 


\section{Appendix}

Reference Values for Laboratory Animals (Research Animal Resources, University of Minnesota, 2013).

Table A1. Normal haematology values.

\begin{tabular}{|c|c|c|c|c|c|c|c|c|c|c|c|c|c|}
\hline & Dog & Cat & Rhesus & Baboon & $\begin{array}{l}\text { Swine } \\
\text { (PIG) }\end{array}$ & Sheep & Cow & Rabbit & $\begin{array}{l}\text { Guinea } \\
\text { Pig }\end{array}$ & Hamster & Rat & Mouse & Gerbil \\
\hline PCV (\%) & $29-55$ & $25-41$ & $26-48$ & $33-43$ & $32-50$ & $24-45$ & $24-48$ & $30-50$ & $37-48$ & $40-61$ & $36-54$ & $39-49$ & $43-60$ \\
\hline Hgb (g/dl) & $14.2-19.2$ & $14.2-19.2$ & $8.8-16.5$ & $10.9-14.3$ & $10-16$ & $8-16$ & $8-15$ & $10-15$ & $11-15$ & $10-18$ & $11-19.2$ & 10.2 - 16.6 & $\begin{array}{c}12.6- \\
16.2\end{array}$ \\
\hline $\operatorname{MCV}(f l)$ & $65-80$ & $65-80$ & $72-86$ & $71.2-82.8$ & $50-68$ & $23-48$ & $40-60$ & & $78-95$ & $67-77$ & $48-70$ & $41-49$ & \\
\hline MCH (pg) & $12.2-25.4$ & $12.2-25.4$ & $18.5-36.6$ & $23.5-27.1$ & $17-23$ & $8-12$ & $11-17$ & & & & & & \\
\hline MCHC (g/dl) & $32-36$ & $32-36$ & $25.6-40.2$ & $31.6-34.2$ & $30-36$ & $31-38$ & $30-36$ & & $27-37$ & $30-34$ & 40 & & \\
\hline WBC $(\times 1000)$ & $5.9-16.6$ & $3.8-19$ & $7-13$ & $3.8-15.5$ & $7-20$ & $4-12$ & $4-12$ & $7-13$ & $4.5-11$ & $5-8.9$ & $6-18$ & $6-15$ & $7-15$ \\
\hline \multicolumn{14}{|l|}{ Diff. (\%) } \\
\hline bands & $0-4$ & $0-1$ & $0-6$ & $0-1$ & 0 - 10 & $0-2$ & $0-4$ & & & & & & \\
\hline lymphs & $8-38$ & $7-60$ & $40-76$ & $9-63$ & $40-60$ & $40-70$ & $40-70$ & $40-80$ & $39-72$ & $50-81$ & $65-85$ & $55-95$ & $60-95$ \\
\hline monos & $1-9$ & $0-5$ & $0-11$ & $0-5$ & $2-10$ & $0-6$ & $1-6$ & $1-4$ & $2-6$ & $0-3$ & $0-5$ & $1-4$ & $0-3$ \\
\hline eos & $0-9$ & $0-12$ & $0-14$ & $0-3$ & $0-10$ & $0-10$ & $0-4$ & $0-4$ & $0-5$ & $0-4$ & $0-6$ & $0-4$ & $0-4$ \\
\hline basos & $0-1$ & $0-2$ & $0-6$ & $0-1$ & 0 - 2 & $0-3$ & $0-2$ & $1-7$ & $0-3$ & $0-1$ & $0-1$ & $0-1$ & $0-1$ \\
\hline plat $(\times 1000)$ & $160-525$ & $160-660$ & $109-597$ & $151-481$ & $120-720$ & $100-800$ & $50-750$ & $125-270$ & $250-850$ & $200-500$ & $500-1300$ & $160-410$ & $400-600$ \\
\hline $\begin{array}{c}\text { Fibrinogen } \\
\text { (mg/dl) }\end{array}$ & $200-400$ & & 118 - 214 & $100-500$ & $100-500$ & $300-700$ & & $263-572$ & $200-300$ & & & & \\
\hline
\end{tabular}

Neutrophil $=45 \%$ for swine . 